Nicole Dołowy-Rybińska

Polska Akademia Nauk

nicoledolowy@gmail.com

\title{
Tradycja, folklor, nowoczesność. Kultura górnołużycka i kaszubska w oczach ich młodych przedstawicieli*
}

\begin{abstract}
Dołowy-Rybińska Nicole, Tradycja, folklor, nowoczesność. Kultura górnołużycka i kaszubska w oczach ich młodych przedstawicieli (Tradition, Folklore, Modernity. Upper Sorbian and Kashubian Culture Through the Eyes of Its Young Representatives). „Poznańskie Studia Slawistyczne" 8. Publishing House of the Poznań Society for the Advancement of the Arts and Sciences, pp. 53-66. ISSN 2084-3011.
\end{abstract}

The article is based on a participatory observation and semi-structured interviews conducted in 2012 and 2013 with young (aged 16-25) Upper Sorbs and Kashubs. They were asked about their perception of the Upper Sorbian/Kashubian culture, its relation with the past, tradition and folklore, reception of the dominant image of their culture and the existence of a modern dimension of the Upper Sorbian/Kashubian culture. An analysis of the young peoples' statements and anthropological research shows that a relation with tradition is still important for minority culture participants although it depends on the way this culture is lived. In the case of the Upper Sorbs some of the traditions, related to the Catholic culture, are alive and constitute an important part of community life. They are perceived as the 'authentic' ones. The Kashubian culture, however, has been strongly folklorized and young people do not identify with the folkloric representations and image of this culture, which is treated as an artificial phenomenon. Young people of both cultures want their culture to be modern yet, at the same time, have a connection with the past.

KeYwords: Kashubs; Upper Sorbs; young people; folklore; folklorization; tradition; minority cultures; modernization

Jeszcze na początku XX wieku europejskie autochtoniczne mniejszości kulturowe funkcjonowały w zamkniętych wspólnotach. Ich przedstawiciele różnili się od otoczenia zwyczajami, strojem, sposobem wykonania pracy, niekiedy religią, zawsze - językiem. Nie tworzyli jednak „wspólnot wyobrażonych” w rozumieniu Benedicta Andersona (1997),

${ }^{*}$ Projekt został sfinansowany ze środków Narodowego Centrum Nauki przyznanych na podstawie decyzji numer DEC-2011/01/D/HS2/02085. 
identyfikowali się z lokalną grupą znanych bezpośrednio ludzi. Sytuacja zmieniła się wraz z wprowadzeniem obowiązkowej, państwowej edukacji, industrializacją, urbanizacją, rozwojem nowych mediów: następowała wówczas coraz szybsza asymilacja kulturowa i językowa mniejszości. Dopiero w ostatnich dziesięcioleciach XX wieku polityka państw europejskich umożliwiła im dążenie do podmiotowości i walkę o uznanie praw, a tym samym tworzenie ponadlokalnej, mniejszościowej tożsamości. Obecnie, wraz z procesami globalizacyjnymi, tożsamość ta staje się coraz bardziej płynna. W wielu miejscach przekaz języków lokalnych bardzo osłabł, a kultura straciła wyrazisty charakter, gdy wspólnoty zrezygnowały z kultywowania tradycyjnych zwyczajów. Odrębność kultur mniejszościowych przetrwała jednak dzięki zorganizowanym działaniom etnicznej elity, stworzeniu instytucji kulturalnych (czasem też politycznych), specjalnych zajęć dla przedstawicieli społeczności, zorganizowaniu szkolnictwa etnicznego, festiwali i konkursów. Wspólnotę kultur mniejszościowych zastąpił stowarzyszeniowy charakter uczestnictwa w życiu zbiorowym (Tönnies 1988).

Zmiana kulturowa i językowa, a jednocześnie coraz silniejsza chęć zachowania i zamanifestowania odrębności doprowadziła do tego, że mniejszości musiały renegocjować swoje granice etniczne (Barth 2004). Aby podkreślić specyfikę kulturową w sytuacji, gdy ich przedstawiciele niczym nie różnią się od reprezentantów kultur dominujących, zarówno same mniejszości, jak i twórcy tejże kultury położyli nacisk na zachowanie i prezentowanie tradycji i folkloru. Pod koniec XX wieku okazało się to jednak niewystarczające. Wizerunek kultur mniejszościowych silnie związanych z folklorem kłóci się nie tylko z koniecznością działania w ramach nowoczesnego państwa i ,projektowego" myślenia o kulturze, ale również z potrzebami młodych ludzi, którzy podejmują świadomą decyzję o przynależności (bądź nie) do tej kultury (Warmińska 2007). Muszą więc znaleźć w niej coś, z czym chcą i potrafią się identyfikować. Wychowani na mediach cyfrowych, przepływie informacji i wielości prądów kulturowych, chcieliby widzieć w kulturze etnicznej wartości im bliskie, móc żyć nią tak, jak żyją innymi kulturami.

Przedstawione w tym tekście wnioski opierają się na kilkuletnich badaniach terenowych, bazujących na obserwacji oraz na wywiadach, które prowadziłam w 2012 i 2013 roku z młodymi (16-25 lat) Górnołużyczanami 
i Kaszubami ${ }^{1}$. Wszyscy moi rozmówcy są zainteresowani uczestnictwem w kulturze mniejszościowej: uczą się języka bądź działają na rzecz jego przetrwania, biorą udział w życiu kulturalnym i/lub politycznym grupy, z którą się na różne sposoby identyfikują. Ich słowa nie są więc reprezentatywne dla całej młodzieży „mniejszościowej”, jednak mają podstawowe znaczenie dla refleksji nad statusem i charakterem mniejszości we współczesnym świecie. Większość rówieśników moich rozmówców nie angażuje się bowiem w życie mniejszości i przejmuje taki jej wizerunek, jaki znajdują w mediach, spotykają na zajęciach etnicznych, podczas uroczystości mniejszościowych, festiwali folklorystycznych itd., czyli sprowadzający ją często jedynie do folkloru, reliktu przeszłości.

Chciałam usłyszeć od młodych ludzi, jaki jest ich stosunek do przeszłości i folkloru, jak odbierają dominujący wizerunek własnej kultury, z jakimi jej aspektami się utożsamiają, jakie znaczenie ma dla nich tradycja oraz jak chcieliby, żeby ich kultura funkcjonowała obecnie. W czasie badań okazało się, że mimo wielu podobieństw, każda z grup boryka się ze specyficznymi dylematami. Prowadzenie komparatystycznych badań antropologicznych uwrażliwia właśnie na te różnice. Wyprowadzenie wniosków dotyczących sposobu funkcjonowania mniejszości we współczesnym świecie powinien poprzedzić przegląd głosów przedstawicieli badanych kultur.

\section{Kultura górnołużycka}

Górnołużyczanie zamieszkują niewielki, wiejski obszar blisko Budziszyna. Szacuje się, że osób posługujących się językiem górnołużyckim jest około dziesięć do dwunastu tysięcy (Elle 2010). W przeciwieństwie do otaczających ich Niemców oraz Dolnołużyczan, którzy ulegli prawie całkowitej asymilacji językowej, część Górnołużyczan jest katolikami ta odmienność religijna miała duże znaczenie dla zachowania odrębności kulturowej i językowej oraz tożsamości słowiańskiej (Walde 2004: 3-27). Prześladowani w czasach hitlerowskich, po II wojnie światowej zostali objęci ochroną: stworzono łużyckie instytucje, szkolnictwo, pozwolono

${ }^{1} \mathrm{~W}$ ramach projektu badawczego obejmującego również Walijczyków i Bretończyków. 
kultywować zwyczaje, na których opierała się ich kultura. Jednak w NRD w przestrzeni publicznej propagowane były przede wszystkim uroczystości folklorystyczne podkreślające ludowy charakter kultury Łużyczan. Inne, polityczne i narodowe cele wspólnoty, mogły być realizowane jedynie w wyznaczonych przez władze granicach. Lata działalności w takich warunkach wywarły wpływ na dzisiejsze Łużyce (Dołowy 2007).

Kultura łużycka wydaje się zanurzona w ludowości. Wszystkim wydarzeniom kulturalnym, świętom kościelnym i wspólnotowym towarzyszą grupy muzyczne i/lub taneczne, prezentujące repertuar zaczerpnięty z kultury ludowej. Przedstawiciele mniejszości, zwłaszcza kobiety, ubierają się w tradycyjne stroje, których posiadanie uważają za oczywiste. Co ciekawe, młodzi Górnołużyczanie, mówiąc o swojej kulturze, często odnoszą się do obrzędów i zwyczajów, które są silnie osadzone w kultywowanej przez wspólnotę wierze katolickiej oraz stanowią dla nich wartość i podstawę identyfikacji. Uważają, że bez religii i języka obrzędowy wymiar ich kultury utraciłby autentyczność:

$\mathrm{B}(\longleftarrow) 22 \mathrm{M}^{2}$ : Myślę, że bycie Łużyczaninem jest też związane z wiarą. Takie mam wrażenie. W niedzielę każdy idzie jeszcze do kościoła. (...) Tam można usłyszeć co prawda zawsze te same czy podobne zdania, ale można usłyszeć zawsze coś po łużycku. To jest częścią całości. Jesteś Łużyczaninem i cóż, tak naprawdę również katolikiem. (...) [ważne] żeby to była wiara żywa, świadoma. (...) Moim zdaniem ludzie są związani poprzez święta, jak Boże Ciało z družkami, są tradycyjne stroje itd.

Zdaniem wielu młodych Górnołużyczan przekazywane z pokolenia na pokolenie zwyczaje konstytuują wspólnotę, wyróżniają spośród otaczających ich Niemców i sprawiają, że ona trwa, że w ogóle - istnieje.

T(Ł)17M: Zwyczaje to sedno tej łużyckości. To to, gdzie starzy i młodzi spotykają się i przekazują sobie te zwyczaje. Moja babcia na przykład nauczyła mnie woskowania jajek i w ten sposób idzie to dalej. Mój młodszy brat też się tego nauczył (...). Moja matka nauczyła się tego od mojej prababci. Tak to się przekazuje, tak zaczyna się przekazywać te tradycje i zwyczaje po łużycku - to piękne. U Łużyczan wszystko się przekazuje, a jeśli się tego nie przekaże dalej, to to zginie.

${ }^{2}$ Oznaczenie wywiadów: B - symbol nadany rozmówcy; (Ł) - Łużyczanin (K - Kaszuba); 22 - wiek; $\mathrm{M}$ - mężczyzna (K - kobieta). Wywiady kaszubskie zostały przeprowadzone po polsku, wywiady na Łużycach - po górnołużycku, a następnie zostały przełożone na język polski z zachowaniem ustnego stylu wypowiedzi. 
Na katolickich Górnych Łużycach istnieje wciąż bardzo silny związek między przynależnością kulturową, językiem oraz udziałem w życiu wspólnotowym. Młodzi zwracają uwagę, że obrzędy nie miałyby znaczenia, gdyby nie język łużycki, który dodatkowo buduje związek między osobami biorącymi w nich udział. Niezależnie od stosunku do samej tradycji młodzi odbierają obrzędy i zwyczaje łużyckie jako autentyczne, będące częścią ich świata, w którym chcą brać aktywny udział:

$\mathrm{P}(\longleftarrow) 22 \mathrm{M}$ : To widać w tym, że są aktualne tematy, konflikty. Także kultura o tym opowiada, np. sztuka teatralna, która odnosi się do pewnego fenomenu i dlatego myślę, że łużycka kultura jest nowoczesna. Także zwyczaje. Wiele ludzi myśli, że nie są współczesne, że to coś archaicznego. Nie zgadzam się z tym, bo one też są współczesne przez to, że zawsze nowe pokolenie prowadzi te zwyczaje. Zwyczaj jest tak współczesny, jak wszystko pozostałe. Tylko dlatego, że to jest tradycja, nie oznacza to, że nie jest to współczesne. To sedno zwyczajów może się odnosić także do dzisiejszego życia.

Zastanawiając się nad istotą zwyczajów i tradycji w swojej kulturze oraz nad uczestnictwem w nich, rozmówcy często odwołują się, jako do przykładu negatywnego, do obrzędowości dolnołużyckiej, odbieranej jako spektakl, któremu brak autentyczności:

M(Ł)25K: Czy łużycka kultura bez łużyckiego dalej będzie istnieć? To jest przykład z Dolnych Łużyc, bo tam tak jest. Mam dwa uczucia - z jednej strony to dobrze, że to jeszcze się tam utrzymuje. Ale z drugiej strony, jak długo może to istnieć bez języka? Nie wiem. Czy to nie jest sztuczne i czy to nie będzie sztuczne? (...) Wtedy to nie jest osobiste. Pewnie [to jest] tylko folklor. Jak długo to będzie trwać? Pewnie tylko kilka pokoleń. Jeśli nie znasz nikogo i tylko mówisz, że moja babcia na Dolnych Łużycach jeszcze umiała mówić po łużycku, jeszcze to pamiętam, że to jeszcze było żywe trzy pokolenia temu, ale nie doświadczyłam tego jako części mojego życia... Wtedy to [funkcjonuje] tylko na jakichś świętach, albo w muzeum. (...) To potem nie jest powszednie. I nie jest tak ważne.

Mimo istotnego przywiązania młodych Górnołużyczan do tradycji i życia obrzędowego, wyznaczającego zakres wspólnoty i odróżniającego ją od kultury niemieckiej, słychać wśród młodych ludzi również krytyczne głosy w stosunku do wizerunku i sposobu funkcjonowania kultury łużyckiej. Zwracają uwagę na podziały między ich życiem łużyckim i niemieckim, postrzeganym jako nowoczesne. Zdając sobie sprawę z wagi tradycji i zachowania ciągłości, czują jednocześnie niewystarczalność kultury mniejszościowej. 
B(Ł)22M: Najczęściej wszyscy starają się trzymać starych tradycji. Ale to się robi, żeby ocalić kulturę łużycką od zapomnienia. Ogólnie panuje strach, że wszystko zaginie, bo się już tego nie używa. Taka jest prawda. Tak sądzę. Współczesnej sztuki trochę na pewno brakuje. PAWK ${ }^{3}$ lub „Satkula” ${ }^{4}$ próbują coś robić współczesnego dla młodzieży. Dobrze, że to robią. Super. Lub SAEK, tam podkładają głosy łużyckie do filmów. Ale jest tego mało.

Nie wszystkim ta kultura wystarcza. Szukają swojego miejsca poza Łużycami i wspólnotą. Wielu młodych - mimo aktywnego uczestnictwa w tradycji - obawia się, że brak modernizacji może szkodzić kulturze łużyckiej, a następne pokolenia odsuną się od niej, gdyż będzie im trudno się $\mathrm{z}$ nią identyfikować.

S(Ł)18K: Myślę, że niektórzy Łużyczanie są zbyt konserwatywni i się bardzo boją współczesnej kultury. I hamują innych, żeby nic nie zmieniali, żeby się nie rozwijali. I wydaje mi się, że to nie jest dobre dla kultury łużyckiej, bo my jednocześnie jesteśmy normalnymi młodymi ludźmi. Nie może być aż takiego rozdźwięku między naszym niemieckim a naszym łużyckim życiem. I to trochę może szkodzić naszej kulturze.

\section{Kultura kaszubska}

W pewnym sensie kultura kaszubska jest najbliższa kulturze łużyckiej - obie należą do słowiańskich kultur mniejszościowych w państwach należących do tzw. bloku wschodniego. Jednak, podczas gdy Łużyczanie w NRD zostali otoczeni ochroną i mogli rozwijać swoją kulturę (w dopuszczonym przez władze zakresie) w wielu dziedzinach życia, Kaszubi, zgodnie z polityką władz zacierania istniejących granic etnicznych, zwani byli „grupą etnograficzną” (Wicherkiewicz 2011: 148), która mogła funkcjonować jedynie pod postacią sfolkloryzowanych wydarzeń kulturalnych. W rezultacie na Kaszubach obrzędy i zwyczaje przestały być konstytutywną częścią życia religijnego. Bliskość dominującej polskiej kultury i języka sprawiła, że Kaszubi ulegli w ciągu ostatniego wieku silnej asymilacji. W PRL-u intelektualny wymiar kaszubskiej kultury (język, literatura) rozwijał się bardzo niszowo (Obracht-Prondzyński 2002). Choć

\footnotetext{
${ }^{3}$ Stowarzyszenie łużyckiej młodzieży.

${ }^{4}$ Program radiowy w języku górnołużyckim przeznaczony dla młodzieży, prezentujący aktualne tematy.
} 
wciąż kilkaset tysięcy ludzi deklaruje tożsamość kaszubską, zaś około stu tysięcy mówi po kaszubsku, większość osób z młodego pokolenia nie zna języka, a z kaszubskością identyfikuje się coraz słabiej (Synak 1998; Mazurek 2010). W młodym pokoleniu można obecnie wyodrębnić kilka postaw, przyjmowanych wobec kultury mniejszościowej. Ci, którzy wyrośli w kaszubskich wioskach i tam poznali, zazwyczaj biernie, język, uczestniczą w lokalnych wydarzeniach kulturalnych, natomiast rzadko mówią otwarcie o swojej tożsamości. Przedstawiciele drugiej orientacji w pewnym momencie odkryli kaszubskie korzenie, nauczyli się języka, zaangażowali w ruch kulturalny/polityczny i manifestują swoją kaszubskość. Do trzeciej, najliczniej reprezentowanej grupy należą osoby obojętne w stosunku do kaszubskości.

Bardzo często niechęć do identyfikacji z kulturą kaszubską wynika z jej folklorystycznego wizerunku, ciągle propagowanego przez polskie media oraz same środowiska kaszubskie:

A(K)20M: Chyba jest z tym jakaś trudność wciąż, bo ta kaszubszczyzna jest w zły sposób sprzedawana. Bardziej się pokazuje taką jej skansenowość. I wtedy młodzież ma często takie poczucie, że to jest taka lekcja historii: jak tu kiedyś było, jak wyglądało życie pokolenia naszych dziadków, więc to nas nie dotyczy. My możemy to obejrzeć, zainteresować się tym, ale nas to nie dotyczy. To wynika ze złego zareklamowania kaszubszczyzny. My nie reklamujemy kaszubskości jako czegoś, co miałoby bezpośrednio kształtować młodych ludzi. I niestety do tego młodzi ludzie muszą dojść sami, tak jak to było w moim przypadku.

Nowoczesna kultura kaszubska jest źle odbierana przez część starszych kaszubskich działaczy, uważających, że tylko folklor odróżnia Kaszubów od Polaków ${ }^{5}$. Z takim postrzeganiem swojej kultury młodzi się stykają i w związku z tym mają silne poczucie, że kultura kaszubska należy do przeszłości, że nie jest i nie może się stać częścią ich życia:

\footnotetext{
${ }^{5} \mathrm{Na}$ udowodnienie tej tezy można przywołać wypowiedź sprzed kilku już lat Franciszka Kwidzyńskiego, kierownika zespołu regionalnego „Kaszuby” w Kartuzach: „Pan, panie Jacku Fopke, chce ubrać Kaszubów w dżinsy. Jak pan sobie to wyobraża? Skąd widz, który przypadkowo przyjdzie na występ, nie czytając plakatu, będzie wiedział, że to Kaszubi? Bo na dżinsach tego nie napiszemy. Nie mogę sobie wyobrazić, jak zespoły rockowe mogą promować Kaszuby bez odrobiny kaszubskiej tradycji” (<www.naszekaszuby.pl/modules/ news/article.php?storyid=370>, 21.05.2014). Choć w ostatnich latach wzrosło przyzwolenie na funkcjonowanie kultury kaszubskiej w nowoczesnej formie, nadal wielu osobom trudno sobie wyobrazić odcięcie się od folkloru.
} 
$\mathrm{U}(\mathrm{K}) 18 \mathrm{~K}$ : Wydaje mi się, że to było, jak kiedyś byłam na przeglądzie orkiestr i właśnie występował tam zespół kaszubski. I wyszły te starsze panie, w tych strojach, zaczęły coś śpiewać, w ogóle nie wiedziałam, po jakiemu to jest... Potem dopiero dowiedziałam się, że to jest kaszubski. I w sumie byłam sceptycznie do tego nastawiona, bo ja kompletnie tego nie rozumiałam. Myślałam, że to jest język dla starszych pań, które zajmują się tylko i wyłącznie szydełkowaniem, siedzą w domu i nic poza tym. (...)

N.D.: Czyli twój pierwszy uświadomiony kontakt z kulturą kaszubską...

$\mathrm{U}(\mathrm{K}) 18 \mathrm{~K}$ : Był taki, że ojej. Bo w sumie tam nie było żadnej młodej kobiety, żadnych dziewczynek i tak mi się wydawało, że to będzie coś takiego.

N.D.: I taki obraz przetrwał aż do liceum?

$\mathrm{U}(\mathrm{K}) 18 \mathrm{~K}$ : Chyba jednak dotrwał do liceum. To było dla mnie takie ortodoksyjne. Takie: to jest folklor, OK, do tego nie trzeba wracać, niech oni sobie tam żyją, ja tego nie potrzebuję. Wydaje mi się, że to było coś takiego.

Ostatnie lata przyniosły wiele zmian. Przede wszystkim Kaszubi zyskali podmiotowość i wypromowali inne, nie tylko folklorystyczne, wymiary życia kulturalnego. Język kaszubski wprowadzono do szkół, znalazł miejsce w nowych mediach. Powstały zespoły muzyczne, również mainstreamowe, śpiewające w tym języku, Kaszubi zaczęli na swojej kulturze zarabiać (Nowicka 2006). Dzięki temu stała się ona atrakcyjna dla młodych, o ile tylko mieli szansę poznać taki jej wymiar. Niestety, jest to wciąż mało rozpowszechniona strona tej kultury:

$\mathrm{O}(\mathrm{K}) 24 \mathrm{~K}$ : Ostatnio kupiłam sobie torebkę filcową z kaszubskim haftem. Teściowa zrobiła mi żółty szalik z czarnym kaszubskim wzorem, wszyscy na uniwersytecie szaleli: „Wow, skąd masz taki szalik?”. Więc ja uważam, że jest modna. Ale nie [dla każdego]. Te takie przaśnie, bogobojne, kapliczkowe Kaszuby modne raczej nie będą. Jeśli spojrzymy tylko na takie Kaszuby, które zostawiają kwiaty pod pomnikami działaczy, jeśli będziemy dbać tylko i wyłącznie o Kaszuby, które stroją kapliczki na święta kościelne, jeśli będziemy dbać tylko o Kaszuby, które robią chleb ze smalcem i ogórka, to to nie ma za bardzo szansy. Jeśli będziemy dbać tylko i wyłącznie o Kaszuby, które chodzą w pięknych strojach stworzonych przez Cepelię, to to nie ma szansy. Ale Kaszubi, szczególnie młodzi, wyszli poza to dalej. I widać, że jest to zainteresowanie.

Młodzi zaangażowani Kaszubi odczuwają więc silną potrzebę propagowania nowego typu kultury kaszubskiej, nowoczesnej, atrakcyjnej i pociągającej dla obojętnych rówieśników. Obawiając się jednak oderwania od tego, co stanowi znak rozpoznawczy kultury kaszubskiej, często włączają jej elementy ludowe do dziedzin i gatunków funkcjonujących współcześnie: 
I(K)22K: Kultura kaszubska to są te elementy, które nas jakoś wyróżniają spośród innych kultur. Więc póki co, jest to przede wszystkim kultura ludowa. Te pieśni ludowe, które są teraz często robione w nowych aranżacjach, co też jest ciekawe i warte posłuchania. Ta sztuka ludowa, która też jest ważna jako element stary, zabytkowy, ale też bardzo dobrze wkomponowuje się w te nowe trendy, np. haft na bluzkach albo jakieś tam elementy użytkowe w domu, np. ręczniki czy narzędzia kuchenne z haftem kaszubskim. (...) dobrze, że się rozwijamy też współcześnie (...). Powstają różnego rodzaju gatunki współczesne, np. komiks kaszubski czy kryminał kaszubski. I to wszystko jest bardzo ważne dla mnie. I dobrze, że to się rozwija równolegle. Z jednej strony ta kultura ludowa i to się kultywuje, i robi się to samo, co kiedyś, i tego się nie wstydzi. I to, co się rozwija swoją drogą jako nowoczesna kultura kaszubska.

Młodzi działacze zdają sobie sprawę, że tym, co łączy starą kaszubskość z nową, a wyzwala z okowów folkloru, jest język. W obliczu uniformizacji kultury kaszubskiej i polskiej, oderwania od miejscowych tradycji i niechęci do folkloru, to język adaptujący się do nowych zjawisk kulturowych gwarantuje istnienie granicy między kaszubskością i polskością. Skoncentrowanie działań na zachowaniu i rozwoju języka kaszubskiego przeraża natomiast tych, którzy starają się doszukać we współczesnej kulturze ,,autentyzmu”, zwanego często „kaszubskim duchem”:

C(K)21K.: Uważam, że [język] jest ważny, ale gdzieś w tym wszystkim zgubiliśmy naszą tradycję, naszą kulturę. I to wszystko gdzieś się zredukowało do minimum na rzecz języka. To tak nie do końca powinno być. (...) musimy się skupić na tym, że Kaszubi czy Kaszuby to nie tylko język, ale też jakaś kultura, historia, tradycja. Dziś zanika obrzędowość, nie mamy już pojęcia, co to jest pusta noc, albo polterabend czy coś. Dzisiaj stawiamy nacisk na język i na gramatykę i po prostu gubimy też bardzo ważne rzeczy.

\section{Mniejszości słowiańskie we współczesnym świecie: między tradycją, folklorem a nowoczesnością}

W tradycyjnym świecie przynależność do wspólnoty, więź kulturowa, religia i zwyczaje dawały ludziom poczucie pewności i stabilności. Tymczasem życie w świecie nowoczesnym jest ciągiem wyborów, które trzeba podejmować bez trwałego oparcia (Barker 2005: 236), bez przekonania co do ich słuszności. Moi młodzi rozmówcy bardzo często właśnie w tradycji szukają uzasadnienia własnych wyborów, gdyż - jak pisała Małgorzata Jacyno (2004: 135) - „świat tradycyjnych form uspołecznienia jawi się z perspektywy nowoczesności jako świat zintegrowany, który 
może dostarczyć jednostkom stałego i pewnego, wyznaczonego granicami wspólnoty horyzontu działania”. Nie sama przeszłość i udział w tradycyjnych obrzędach ma znaczenie, ale możliwość odwołania się do nich, potwierdzenia swojego miejsca w nowej konfiguracji wartości i odniesień. Więcej nawet: młodzi ludzie, z którymi rozmawiałam, przyznają otwarcie, że dla nich przynależność do mniejszości i angażowanie się na jej rzecz, wiąże się ze świadomie podjętą decyzją. W ich przypadku sięganie do tradycji jest strategią tożsamościową, sama tradycja zaś podlega refleksji. Badaczka pisała: „W tych warunkach tradycja nie jest już systemowym «mechanizmem» odtwarzania przeszłości, a staje się indywidualnie konstruowanym i wybieranym kontekstem interpretacji i reinterpretacji aktualnego doświadczenia uczestnika" (Jacyno 2004: 133). W powoływaniu się na tradycję nie chodzi już o potwierdzanie istnienia pewnego układu norm i wartości, na których opiera się wspólnota, ale o wykorzystanie ogólnie znanych narracji, obrazów, symboli przypisanych danej kulturze, aby potwierdzić jej istnienie (Lubaś 2008: 42).

Młodzi Górnołużyczanie, z którymi rozmawiałam, aktywnie i od dziecka uczestniczą w zorganizowanych przez wspólnotę zwyczajach. Nie wszyscy je lubią, nie dla każdego uczestnictwo to jest atrakcyjne nie o to jednak w nim chodzi. Celem jest podtrzymanie więzi z ludźmi, którzy biorą w nich udział obecnie oraz tymi, którzy dane tradycje kultywowali w przeszłości (Shils 1984: 44). Mimo próby zachowania zwyczaju w takiej formie, jaka funkcjonowała wcześniej, pewne modyfikacje są dozwolone, gdyż zamysłem nie jest tu bezrefleksyjne powtarzanie, ale wyodrębnienie tych wartości, które w świadomości obecnie żyjących stanowią własność ich kultury (Szacki 2011: 137). Tradycja bowiem może być modernizowana, ponieważ powinna być częścią życia osób biorących udział w wydarzeniach kulturalnych. Trafnie ujął to Clifford, pisząc, że „Dwudziestowieczne tożsamości nie zakładają już ciągłości kultur czy tradycji. Wszędzie jednostki czy grupy improwizują lokalne przedstawienia ze zgromadzonych przeszłości, używając obcych mediów, symboli i języków" (Clifford 2000: 22).

Z modernizacją zachowań zrytualizowanych problem mają natomiast niektórzy przedstawiciele kultury kaszubskiej. Zestawienie postaw młodych ludzi pochodzących z kultury górnołużyckiej i kaszubskiej pokazuje w sposób dobitny różnicę między istnieniem we współczesnym świecie 
folkloru jako ludowej twórczości artystycznej, dostosowanej do potrzeb i stylu życia pewnej grupy, przekazywanej z pokolenia na pokolenie i jednocześnie przetwarzanej oraz tworzonej na nowo w odpowiednich sytuacjach (Burszta 1974: 76), a folkloryzmem. To drugie zjawisko, od którego usilnie chcą uciec młodzi Kaszubi, ,polega na celowym stosowaniu w szczególnych sytuacjach bieżącego życia wybranych treści i form folkloru (...) odtwarzanych w sytuacjach celowo zaaranżowanych" (Burszta 1974: 311). W tak odegranym folklorze brak autentyzmu, zostaje bowiem wtłoczony w sztuczne ramy widowiska, odgrywanego dla obserwujących, nie zaś przeżywanego przez uczestników. Kaszubskie, sfolkloryzowane elementy kultury, w przeciwieństwie do percypowanych przez społeczność obrzędów górnołużyckich, są jednowymiarowe, nastawione wyłącznie na przeżycia artystyczno-estetyczne (Burszta 1992: 199). Przeżycia te nie są jednak dla młodych Kaszubów atrakcyjne. Uważają je za „sztuczne” i nie potrafią się z nimi utożsamiać.

Młodzi z mniejszości badanych przeze mnie czują niechęć do powszechnie promowanego wizerunku kultur mniejszościowych jako tradycyjnych, zamkniętych w czasoprzestrzeni, których przedstawiciele zachowują się w sposób odmienny i kultywują prastare zwyczaje. Niechęć ta - co najbardziej widoczne jest w rozmowie z Górnołużyczanami - nie wiąże się z negatywnym stosunkiem do tradycji, gdyż o jej wadze mówią niemal wszyscy. Również Kaszubi odwołują się do tradycyjnych wartości kultury kaszubskiej, takich jak pracowitość, wiara, rodzina. Młodzi sprzeciwiają się natomiast folkloryzacji swoich kultur. Folkloryzacja jest zaś podstawową strategią stosowaną wobec ,innych” przez europejskie kultury dominujące ${ }^{6}$. Służy uproszczeniu znaczeń estetycznych i semantycznych skomplikowanej całości kulturowej, odseparowaniu ich i ułożeniu w nową całość. Elka Tschernokoshewa (2004: 231) twierdzi, że folklorystyczny obraz Łużyczan jest konstrukcją stworzoną na potrzeby kultury dominującej: poprzez ukazywanie kultury łużyckiej w opozycji do niemieckiej, odgradza się je od siebie i tworzy jasne podziały przynależności. W ten sposób po stronie kultury łużyckiej zostają święta i obyczaje związane z tradycjami, po stronie zaś kultury niemieckiej jest świat nowoczesny,

${ }^{6} \mathrm{~W}$ innych miejscach folkloryzację zastępuje ,egzotyzacja”: przedstawianie mniejszości jako intrygujących swą innością atrakcji. 
media, aktualności. Tym samym potwierdzona zostaje wyższość kultury dominującej, gdyż folklorowi nadaje się charakter ekspresji prostej, ludowej kultury, która nie uległa modernizacji i nie wytworzyła kultury wysokiej, elitarnej, świadczącej o jej rozwoju i dojrzałości.

$\mathrm{Na}$ takim właśnie wizerunku wychowane są dzieci należące do europejskich kultur mniejszościowych: udział w nich przedstawia się jako pójście po szkole na próbę zespołu, ubranie się w tradycyjny strój, wykonanie odpowiedniego tańca, śpiewanie ludowych piosenek. Dorastająca młodzież coraz częściej ucieka z tak zorganizowanego życia mniejszościowego, gdyż czasem bywa wyśmiewana przez rówieśników należących do bardziej prestiżowych kultur lub po prostu udział w takich przedsięwzięciach przestaje jej odpowiadać. Jak wszystkie inne nastolatki, przedstawiciele mniejszości chodzą na imprezy, piją alkohol, tańczą na dyskotekach, oglądają seriale w telewizji, grają na komputerze. Nie zależy im na uczestnictwie w kulturze mniejszościowej, jeśli w żaden sposób nie odpowiada ono ich życiu, zainteresowaniom, gustom. Ten problem zauważają zarówno Kaszubi, jak i Górnołużyczanie, dla których wymiar obrzędowy jest ważny, jednakże buntują się przeciw sprowadzaniu wszystkich zajęć etnicznych do folkloru. Młodzi Kaszubi właśnie w folkloryzacji swojej kultury upatrują źródła niechęci do identyfikacji z nią, Górnołużyczanie boją się natomiast, że w zderzeniu ze światem współczesnym kultura łużycka będzie zanikać.

Wybór, przed którym stają młodzi ludzie, nie jest więc oparty jedynie na opozycji między tradycją a nowoczesnością. Jest to wybór między autentyzmem i sztucznością. Wydaje się, że kultury mniejszościowe będą istnieć tak długo, jak długo dla przedstawicieli młodego pokolenia będą atrakcyjne i pozwolą na identyfikację. Ta zaś możliwa jest wtedy, gdy uczestnicy znajdą miejsce do realizacji własnych potrzeb, gdy będą swą mniejszościową kulturę odczuwać jako „prawdziwą”, ,swoją”, a nie „odgrywaną”. Całkowite oderwanie się od przeszłości, tradycji, a nawet sfolkloryzowanych treści kultury mogłoby jednak wywołać poczucie braku odrębności i nieistnienia granic etnicznych między kulturą mniejszościową a dominującą czy nawet globalną. W tym zjawisku tkwi największy problem stojący przed liderami etnicznymi, gdyż młodzi ludzie nie chcą żyć w skansenie, wystawiać się na pokaz, demonstrować, że są „inni”. Poszukiwane są więc takie rozwiązania, dzięki którym - przy za- 
chowaniu odrębności własnej kultury - upodabnia się ją do świata dominującego. W dużej mierze proces ten wiąże się $\mathrm{z}$ dostosowywaniem motywów kultur tradycyjnych do form charakterystycznych dla współczesnego świata, co najbardziej widoczne jest w muzyce oraz twórczości słownej. Język bowiem jest tym aspektem kultury mniejszościowej, który najlepiej adaptuje się we współczesności i w najprostszy sposób poświadcza, że dany człowiek, wydarzenie, spektakl związane są z mniejszością. Dlatego tam, gdzie język mniejszościowy funkcjonuje jako podstawowy środek komunikacji wewnątrzwspólnotowej (np. na Górnych Łużycach katolickich), łatwiej jest młodym odróżnić to, co mniejszościowe, od tego, co dominujące. $Z$ tego też powodu kaszubscy działacze podkreślają, że bez języka kultura kaszubska zniknie i kładą nacisk na odtwarzanie wspólnot przekazu. Pytanie, czy kultura mniejszościowa może być nowoczesna, jest więc źle zadane. Każda kultura może być nowoczesna, jeśli jest tworzona i przeżywana przez nowoczesnych ludzi.

\section{Literatura}

Anderson B., 1997, Wspólnoty wyobrażone. Rozważania o źródlach i rozprzestrzenianiu się nacjonalizmu, przeł. S. Amsterdamski, Warszawa.

Barker C., 2005, Studia kulturowe. Teoria i praktyka, przeł. A. Sadza, Kraków.

Barth F., 2004, Grupy i granice etniczne: społeczna organizacja różnic kulturowych, przeł. M. Głowacka-Grajper, w: Badanie kultury. Elementy teorii antropologicznej. Kontynuacje, red. M. Kempny, E. Nowicka, Warszawa, s. 348-377.

Burszta J., 1974, Kultura ludowa - kultura narodowa. Szkice i rozprawy, Warszawa.

Burszta W., 1992, Wymiary antropologicznego poznania kultury, Poznań.

Clifford J., 2000, Ktopoty z kultura. Dwudziestowieczna etnografia, literatura i sztuka, przeł. E. Dżurak et al., Warszawa.

Dołowy N., 2007, Czy Łużyczanie są mniejszościa wzorcową?, „Zeszyty Łużyckie” nr 41, s. 50-59.

Elle L., 2010, Sorben-demographische und statistische Aspekte, w: Minderheiten als Mehrwert, red. M.T. Vogt, J. Neyer, D. Bingen, J. Sokol, Frankfurt am Main, s. 309-318.

Jacyno M., 2004, Tradycja jako kontekst. Strategie rekonstrukcji przeszłości w autonarracji biograficznej, w: Oblicza lokalności. Tradycja i wspótczesność, red. J. Kurczewska, Warszawa, s. 133-147.

Lubaś M., 2008, Wprowadzenie. Tradycja a zmiana społeczna, w: Tworzenie i odtwarzanie kultury. Tradycja jako wymiar zmian spolecznych. Studia z dziedziny antropologii społecznej, red. G. Kubica, M. Lubaś, Kraków, s. 9-29. 
Mazurek M., 2010, Język, przestrzeń, pochodzenie. Analiza tożsamości kaszubskiej, Gdańsk.

Nowicka E., 2006, Etniczność na sprzedaż i/lub etniczność domowa, w: Mniejszości narodowe w Polsce w świetle Narodowego Spisu Powszechnego z 2002 roku, red. L. Adamczuk, S. Łodziński, Warszawa, s. 285-301.

Obracht-Prondzyński C., 2002, Kaszubi. Między dyskryminacją a regionalna podmiotowościa, Gdańsk.

Shils E., 1984, Tradycja, w: Tradycja i nowoczesność, red. J. Kurczewska, J. Szacki, Warszawa, s. 30-90.

Synak B., 1998, Kaszubska tożsamość: ciagłość i zmiana. Studium socjologiczne, Gdańsk.

Szacki J., 2011, Tradycja, Warszawa.

Tönnies F., 1988, Wspólnota i stowarzyszenie. Rozprawa o komunizmie i socjalizmie jako empirycznych formach kultury, przeł. M. Łukasiewicz, Warszawa.

Tschernokoshewa E., 2004, Constructing Pure and Hybrid Worlds: German Media and 'Otherness', w: Communicating Cultures, red. U. Kockel, M.N. Craith, Münster, s. $222-242$.

Walde M., 2004, Demographisch-statistische Betrachtungen im Oberlausitzer Gemeindeverband „Am Klosterwasser”, „Lětopis” nr 51, s. 3-27.

Warmińska K., 2007, Nowe perspektywy badań nad tożsamościa - próba oceny kaszubskiej etniczności, w: Kim sq Kaszubi? Nowe tendencje w badaniach spotecznych, red. C. Obracht-Prondzyński, Gdańsk, s.103-111.

Wicherkiewicz T., 2011, Language Policy and the Sociolinguistics of Kashubian, w: The Kashubs: Past and Present, red. C. Obracht-Prondzyński, T. Wicherkiewicz, Bern, s. 141-177. 